June - 2016

\title{
The Influence of Biographical Factors on Adult Learner Self-Directedness in an Open Distance Learning Environment
}

Jo-Anne Botha and Mariette Coetzee

Unsia

\begin{abstract}
This study investigated the relationship between self-directedness (as measured by the Adult Learner Self-Directedness Scale) and biographical factors such as age, race, and gender of adult learners enrolled at a South African open distance learning (ODL) higher education institution. Correlational and inferential statistical analyses were used. A stratified random sample of 1,102 mainly black and female learners participated in the study. The Adult Learner Self-Directedness Scale (ALSDS) identified four constructs of adult learner self-directedness in an Open Distance Learning Higher Education (ODLHE) milieu, namely the strategic utilisation of officially provided resources, engaged academic activity, success orientation for ODLHE, and academically motivated behaviour. The research indicated that significant differences exist between the gender, race and age groups with regard to self-directedness.
\end{abstract}

With regard to gender, males scored significantly higher than females on success orientation for ODLHE and engaged academic activity. With regard to race, Indian participants scored significantly higher than the other race groups on strategic utilisation of officially provided resources and engaged academic activity. The white participants scored significantly higher than the other race groups on success orientation for ODLHE. In terms of age, the age group $>50$ scored significantly higher than the other age groups on success orientation for ODLHE and self-efficacy. In terms of success orientation, the means for the age groups seem to increase as the ages of participants increase. The age group 18-25 scored significantly higher than the other age groups on engaged academic activity.

Keywords: Adult student self-directedness, success orientation, engaged academic activity, adult learner, lifelong learning

\section{Introduction}

Higher education, and specifically open distance learning is precariously balanced between the perceived opportunities unlocked by advances in integrated communication technology, and the crisis of ever shrinking funds and ever increasing demands for accountability on the spending of said funds for higher education (Sumner, 2000). In the post-modern or technological era, the prospective 
students of tertiary education want to complete their courses speedily, and with the convenience of being able to choose whether they participate in person, online, or by using a hybrid model.

In the African context, universities are feeling the pressure to participate in global conversations on and make significant contributions to ODLHE environments because of the perceived benefits of technology-based distance education for developing countries (Ivala, 2011; Seta, Kukulska-Hulme \& Arrigo, 2014). At the same time, employers in the South African labour market indicate that graduates do not possess the specific competencies required to effectively function in a specific job (Potgieter, Coetzee, \& Masenge, 2012).

In this multi-faceted milieu, the question can be asked: "What is the purpose of tertiary institutions in an economy and a country?" Is it safe to assume that tertiary institutions should transfer knowledge from the academic to the student? Or, in the face of the widely available information in the information age, would it be more appropriate to cultivate and nurture the capacity for independent thinking in tertiary education students? And, if one accepts the last statement as the most accurate purpose of tertiary institutions, what are the strategies involved in cultivating and nurturing the necessary capacity for independent thinking?

Lifelong learning has been mooted as the panacea for employees to successfully deal with unrelenting technology-driven changes in business organisations (Faber, Lopez, \& Prescher, 2012). When one considers that learning in its most essential form is about growing, one can argue that lifelong learning without the capacity to plan for and successfully implement relevant strategies for continued growth is ineffective (Faber et al., 2012). Lifelong learners should be self-directed in their learning in order to successfully manage their own sustained employability (Cassidy, 2011; Kasworm, 2011; Väljataga \& Laanpere, 2010).

Lifelong learning can only be an effective vehicle for sustained growth and development if the students are successful. The questions about student success investigated include student motivation, student engagement, student persistence, and academic success (Goomas \& Clayton, 2013; Moore, 1990; Pretorius, Prinsloo, \& Uys, 2009; Shillington, Brown, MacKay, Paewai, Suddaby, \& White, 2012; Subotzky \& Prinsloo, 2011; Wardley, Bélanger, \& Leonard, 2013). However, little research has been done on the inherent capacities of adult students, such as student self-directedness, that may influence success specifically in ODLHE environments (Botha, 2014; Coetzee \& Botha, 2013). According to Subotzky and Prinsloo (2011), three connected spheres of elements affect student success in ODLHE, namely uniquely personal factors (including inherent capacities), specific organisational factors, and factors extraneous to the institution. This article reports on the first element of unique personal factors (biographical differences) that influence the self-directedness of adult learners in an ODLHE environment, as measured by the Adult Learner Self-Directedness Scale (ALSDS) which was specifically developed for use in the South African ODLHE environment (Botha, 2014). The significant differences identified in this study contribute to the body of knowledge of the students involved in open distance higher education in South Africa and may assist in the development of learning contexts suitable to specific students. No other South African research study has reported specifically on this matter. 


\section{Background}

Lifelong learning and employability have both been under the spotlight for some time in relation to sustaining economic success globally (Faber et al., 2012; Ivala, 2011). The new university, offering online and blended learning methods, is mooted as the most appropriate vehicle to ensure that employees remain successful lifelong students capable of pro-actively managing their own employability (Botha 2014, Faber et al 2012; Ivala 2011). The technology-based learning approaches used in the new universities should facilitate the development of learning environments that nurture learner autonomy in learning (Heydenrych \& Prinsloo, 2010).

Specific inclinations of adult learners may predispose them towards ODLHE because of its flexibility, ease of access, and the opportunities for collaboration (Karakas \& Manisaligil, 2012). Adult learners learn in assorted surroundings, including social environments, workplaces, through online provision, and in tertiary settings (O’Toole \& Essex, 2011). Usually, adult participation in learning interventions is driven by a personal need to find clarity on a specific issue or to prepare for a new job or life role. Adults as learners have little tolerance for poorly constructed and delivered learning interventions and will judge the relevance and/or applicability of any learning experience with regard to their personal life experiences and realities (Knowles, 1984; O’Toole \& Essex, 2011). In a tertiary institution dealing with adult learners, it is therefore incumbent upon the designers and facilitators of learning experiences to ensure that adult learners perceive or judge their learning as personally valuable, relevant, and applicable (Botha, 2014).

The open distance learning institution in this study makes use of a blended learning approach. Combinations of online and printed study material are used for teaching. Students are expected to proceed with their studies according to due dates in terms of the submission of assignments and the examination. Certain modules are offered on-line only. Although assignments are completed and submitted on line, examinations are mostly still venue based. Students are required to consult additional sources and to complete activities but they could opt not to do so. Online discussion forums are created for all modules but participation is voluntary. Various online module tools are made available to assist students but the utilisation of these tools is the student's choice. Students seldom meet their lecturers in person. In some modules, E-tutors have been appointed to provide student support and additional tutoring. Contact between e-tutors and students takes place telephonically or via e-mail.

\section{Adult Learner Self-Directedness}

Adults as learners are usually fairly sophisticated and independent, thus possessing the capacity to act independently and self-directed (Botha, 2014, Knowles, 1984). Research supports the dictum that students' motivation and psychological attributes influence their learning self-directedness. Oliviera and Simoes (2006) found that a strong relationship exists between students' self-confidence and their self-directedness, while a weaker, but statistically significant relationship exists between selfdirectedness and internal control beliefs. In addition, a collaborative relationship between the academic and the adult learner fosters the cultivation of both motivation and autonomy in the adult student (Garrison, 1997; Taipjutorus, Hansen, \& Brown, 2012). For the purpose of this article, adult learner self-directedness will be described as the capacity to pre-emptively be an active agent in one's own learning and growth (Botha, 2014). 
The desire to engage in integrated (deep) learning in order to construct personally meaningful knowledge is the core of learner self-direction (Garrison, 1997; Taipjutorus et al., 2012). Learner selfdirectedness or autonomy is influenced by diverse factors such as self-knowledge, learning milieu, stimulus for learning, student tenacity, and immersion in the learning material (Cassidy, 2011). Learner self-directedness manifests in student behaviour that reflects active student engagement in the learning process, a drive for deep learning and meta-cognitive engagement (Cassidy, 2011; Edmonson, Boyer, \& Artis, 2012; O’Toole \& Essex, 2012). Self-directed learning is not only about ensuring academic success, but also about being aware of and guiding one's academic behaviour to ensure optimal learning, with a heavy emphasis on students' meta-cognition of their personal confidence in their possible success in learning, learning behaviour, persistence, and learning strategy success (Cassidy, 2011, Pretorius et al., 2009). Self-perception, self-management, and self-reflection are common elements in self-directed learning, each being underpinned by affective, cognitive, and behavioural elements. The ideal outcome of an ability and willingness to be self-directed is the capability to change personal beliefs and to influence the beliefs of others - a cognitive process called autopoiesis (self-invention) or transformative learning (Canning, 2010; Cassidy, 2011; Mezirow, 2000; Prinsloo, Muller, \& Du Plessis, 2010). Knowles (1984) suggested that self-directedness in adult learners existed on a scale from dependent learner to independent learner, and with variations of learner self-directedness in between (Botha, 2014).

\section{The Need for Self-Directedness of Adult Learners in an ODLHE Environment}

The student profile of learners in an ODLHE environment indicates that the majority of learners work full time and, therefore, they study at night and during week-ends (Magagule \& Ngwenya, 2004; Stevens \& Switzer, 2006; Subotzky \& Prinsloo, 2011; Tucker, 2003). The learning process is more complex for distance learners than those at contact institutions because they face diverse challenges. Adult learners in distance education may feel isolated, they may struggle with technology, they may experience a lack of support from their lecturers and they may experience difficulty in interacting with the lecturers and fellow learners. These challenges may lead to frustration which may, in turn, influence the motivation levels of these learners (Dzakira \& Idrus, 2003; Subotzky \& Prinsloo, 2011). Distance education learners also experience external pressures from areas as diverse as their jobs and families, financial constraints, being the first student in a family to enrol for higher education, language difficulties, and a lack of adequate primary education. These factors may all affect their ability to study in a motivated and goal-directed way (Prinsloo, 2009; Subotzky \& Prinsloo, 2011).

In higher education, a balance exists between the actions taken by the institution and the actions taken by the student (Botha, 2014; Garrison, 1997). The university creates a learning environment, while the student deliberately decides to either participate, or remain uninvolved in the created environment. According to Väljataga and Laanpere (2010), learner control of the learning environment, or even the creation of a personal learning environment, contributes to the cultivation of adult learner self-directedness. Thus, the more control the student accepts and carries out in the learning environment, the better the cultivation of learner self-directedness. A learning milieu created by a tertiary or work-based institution transforms into an individual personal learning environment when the adult learner actively controls the environment. A personal learning environment, like an open system, influences and is influenced by external elements such as the tertiary institution, peers and family (Väljataga \& Laanpere, 2010). 
Given the challenges experienced by learners in an open distance learning environment, this study aimed to explore the influence of biographical factors on adult learner self-directedness at a university with mainly African (black) students, who are also historically previously disadvantaged. The purpose of investigating the influence of biographical factors on adult learner self-directedness in this context is to propose approaches to learning environment design that will be inclusive of the majority of the student profile. The need for developing and providing a learning environment conducive to lifelong learning is necessitated by the need to improve the employability of students. While employers may be content with the subject-or domain-specific skills that their employees acquire during tertiary education, there are indications of increased dissatisfaction with the employability skills of employees (Cassidy, 2006; Griesel \& Parker, 2009; Markes, 2006; Potgieter, Coetzee, \& Masenge, 2012). Given the fact that the majority of students at this university come from previously disadvantaged groups (Blacks, women), it would thus make sense to create learning environments that would focus on the employability of these groups of students.

The imperative for lifelong learning has been widely debated in the literature for quite some time (Cassidy, 2011; Faber et al., 2012; Kasworm, 2011; Väljataga \& Laanpere, 2010). Engagement in lifelong learning is essential for individual and economic sustainability and growth (Faber et al., 2012; Ivala, 2011). However, little information exists on the influences biographical factors have on learners' capacity to engage in lifelong learning, which by its nature implies a self-directed approach to personal growth (Botha, 2014; Faber et al., 2012, Richardson, 2011).

\section{Model of Adult Learner Self-Directedness}

Botha's (2014) model of adult learner self-directedness in ODLHE settings endeavours to unify the contextual, behavioural, and psychological elements of adult student self-directedness so as to determine adult ODLHE students' position on the self-directedness continuum (Botha \& Coetzee, 2013). The components of Botha's (2014) model of adult learner self-directedness is illustrated in Figure 1. 


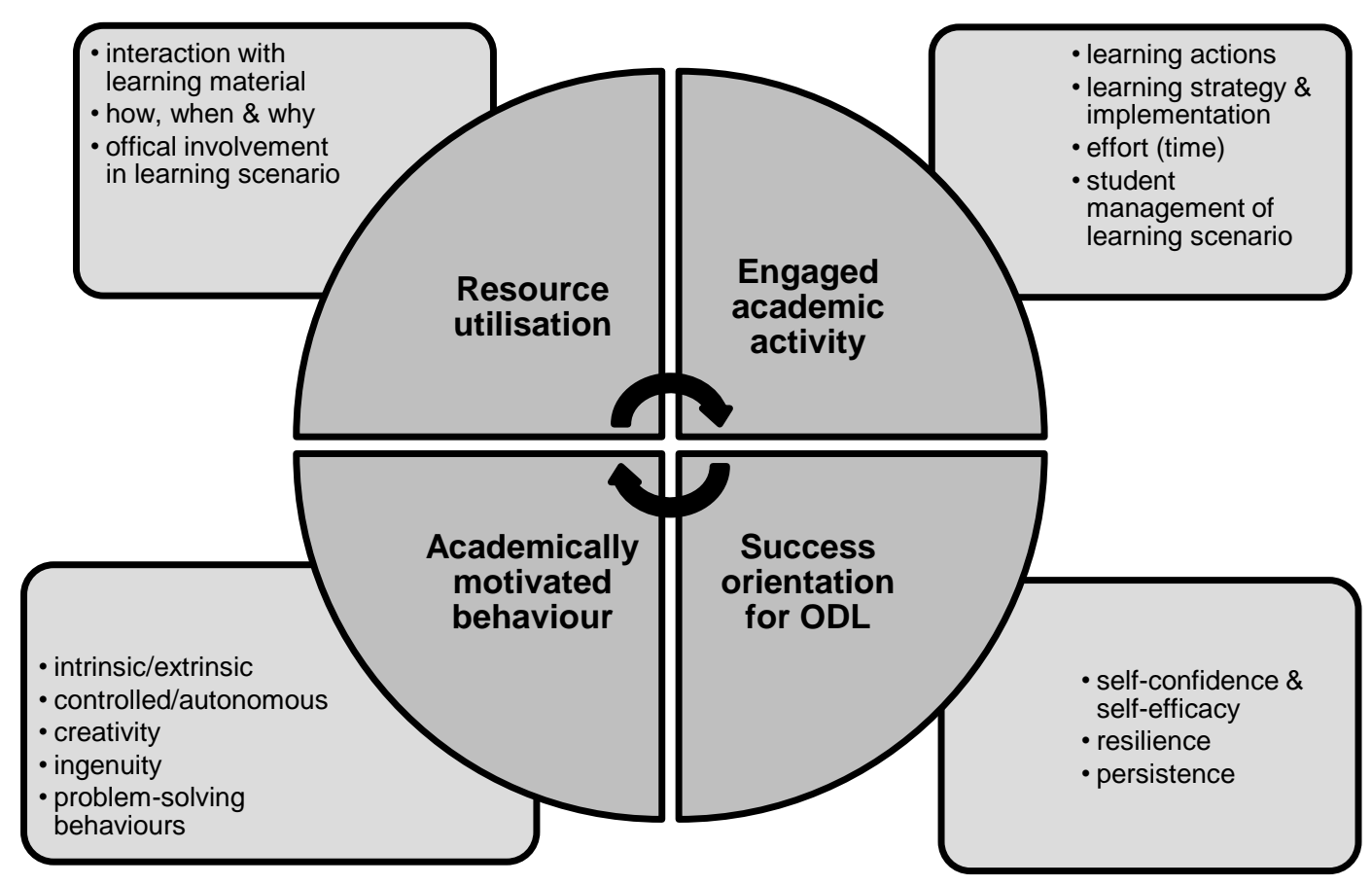

Figure 1. Model of self-directedness.

Botha's (2014) model of self-directedness in ODLHE investigates adult student self-directedness in terms of both the educational setting and the student's unique contributions to the learning. The educational setting is described in terms of the way students utilise the resources provided by the university, as well as the students' engaged academic activity - the students' observable behaviours in the university's learning environment. In the ODLHE context, the learning environment is virtual and loosely defined by whatever learning materials the university provides (Botha, 2014; Coetzee \& Botha, 2013). Students' engaged academic activity is described as the way the students control the learning environment created by the university and are the observable behaviours associated with utilisation of university resources (Botha, 2014; Coetzee \& Botha, 2013).

Successful learning requires not only utilisation of and engagement with a learning environment, but also personal dispositions and attributes that facilitate success (Coetzee \& Botha, 2013). Success orientation for ODLHE signifies the internal dispositions of adult learners that facilitate success, while academically motivated behaviours describe the observable behaviours of adult learners that imply the presence of at least some of the personal dispositions described by success orientation for ODLHE (Botha, 2014; Coetzee \& Botha, 2013). The four elements described in this model represent adult learner self-directedness in ODLHE (Botha, 2014).

\section{Influence of Biographical Factors on Self-Directedness in an ODLHE Environment}

In ODLHE adult learner self-directedness can be seen as the link between the students' control of and involvement in the officially created learning environment on the one hand, and the students' intrinsic beliefs, attitudes and concomitant learning behaviours on the other hand. However, learners' biographical factors such as age, race, and gender may also have an influence on their selfdirectedness. Developers of learning environments in higher education ODL should consider learner profiles in the development of teaching and learning in order to optimise the fit between the individual learner and the ODLHE environment so that student success is supported (Botha, 2014). 


\section{Gender}

According to Huang (2013), North American and European female students apparently possess less well-developed academic self-efficacy than men. Research done by Yahya and Javad (2014) indicated that differences between male and female students were statistically significant with regard to written performance. These results were supported by a study done on the school performance of children and adolescents. According to the results, females performed substantially better than males with regard to writing and reading (Diniz, Piccolo, Couto, Salles, \& Koller, 2014). Conversely, in a South African study focusing on the academic self-efficacy of all students in a technology teacher programme with electricity as the subject, the female students were found to possess lower levels of self-efficacy (Mackay \& Parkinson, 2008). The study found that female students were culturally discouraged to participate in technology- or science-related subjects. On the other hand, male students were culturally encouraged to participate in such subjects and were expected to perform well in them (Mackay \& Parkinson, 2008). In a 2013 study, Chan, Liu, Sung, Lin, Chen, and Cheng (2013) found significantly lower perceived levels of Internet self-efficacy in female students.

\section{Race}

According to research done by Rehfuss (2005) on the self-directedness of medical students in the US, ethnicity accounted for a significant proportion of unique variance in predicting academic performance. Richardson (2013) found no dissimilarity in the academic engagement of students of different racial groups, while male students in a science course were reportedly more engaged than female students (Hampden-Thompson \& Bennett, 2013). Most of the research findings reported were based on studies in first world countries with almost no research on the variables that may affect the self-directedness of adult South African students in ODLHE. There is a paucity of research that focuses specifically on divergence in the workplace and on learner demographics such as race, gender, age and socio-economic background as well as on how these relate to the self-directedness and employability attributes of adult learners. Demographic indicators such as age, race and gender may all influence the success of ODLHE studies (Du Plessis, Prinsloo, \& Muller, 2005; Subotzky \& Prinsloo, 2011; Walker, Matthew, \& Black, 2004) and it is envisaged that the study reported on in this article will provide valuable information in this regard.

\section{Age}

Liddell (2008) found no relationship between readiness for self-directed learning and age, while Oliveira and Simões (2006) found that an indirect relationship exists between self-directedness, age and education level. Reio and Davis (2005) found a positive relationship between readiness for selfdirected learning and age, but no noteworthy relationship between readiness for self-directed learning and gender. According to Reio and Davis (2005), a significant increase in readiness for self-directed learning was detected as age increased. This may possibly be explained by the multifaceted life roles and responsibilities of the learners in older age groups.

\section{Research Methodology}

\section{Population and Sampling}


The population in this research project comprised adult learners enrolled for undergraduate studies in the economic and management sciences field at a comprehensive ODL university. At the time of the study, the total population constituted approximately $\mathrm{N}=438,055$ adult learners. Given the fact that previous research indicated that female learners exhibit lower self-efficacy related to learning in the sciences, this study focusing on undergraduate students in economics and sciences may influence the results.

A stratified, proportional, random sample of $\mathrm{N}=10,500$ of individuals from different gender, race and age groups was drawn from the total population. In addition, the sample was stratified according to module (year level), qualification, department and school. As indicated in Figure 2, the gender groups consisted of $37.2 \%$ males and $62.8 \%$ females.

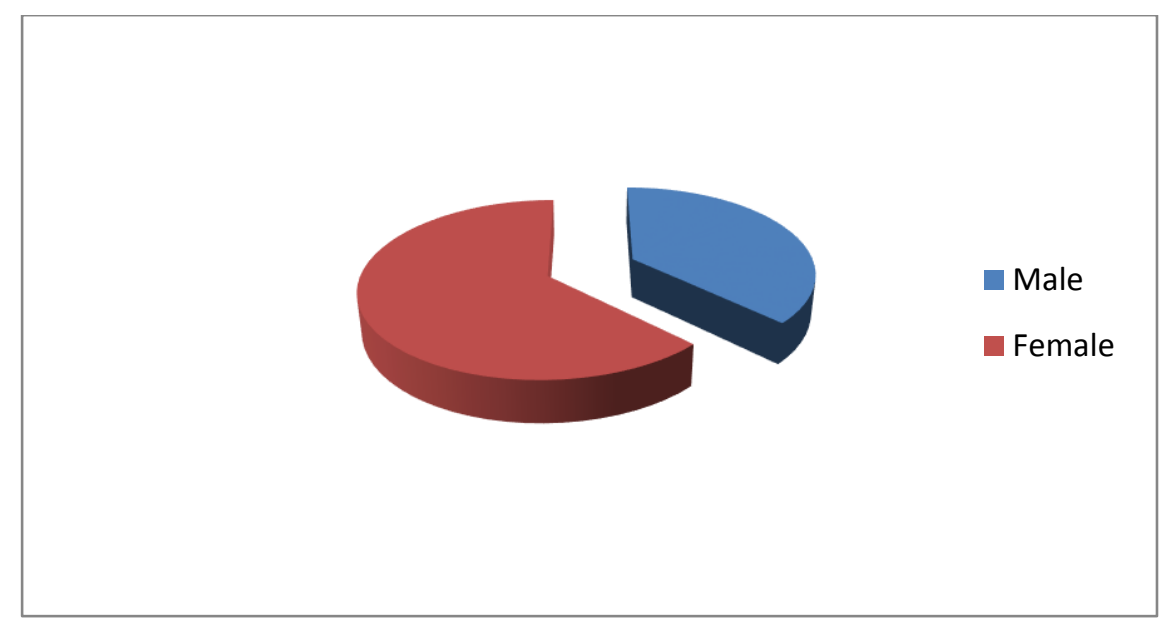

Figure 2. Composition of the gender groups.

Figure 3 indicates that the four race groups represented in this sample consisted of $86.3 \%$ Blacks (Africans), 3.5\% Coloureds, 2.7\% Indians, and 7.4\% Whites.

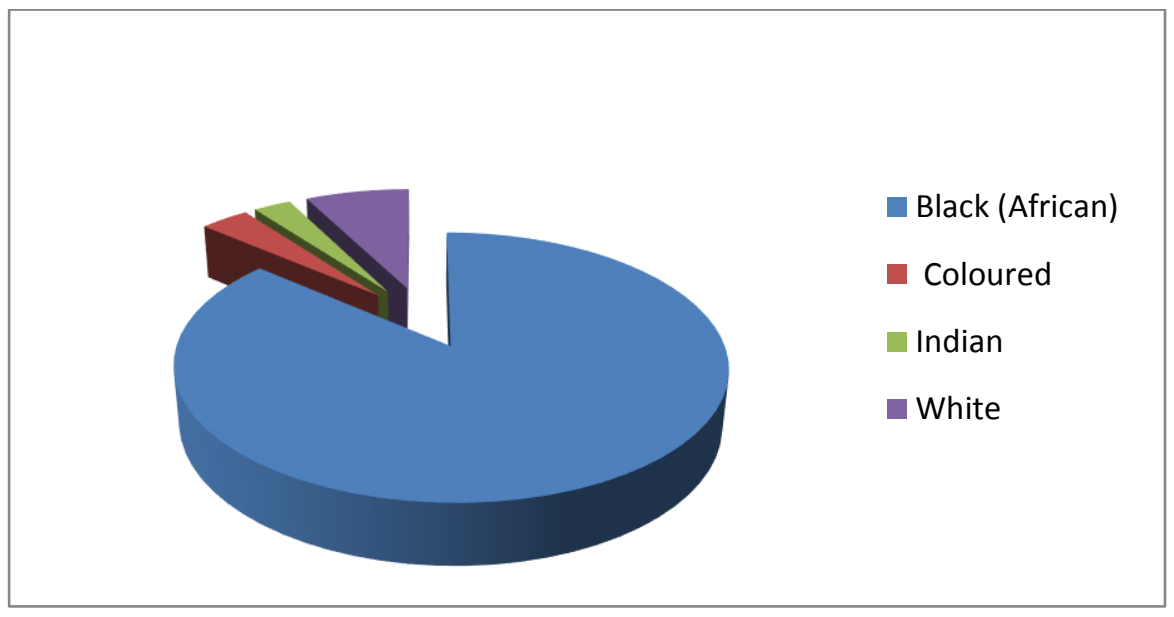

Figure 3. Composition of the race groups. 
Figure 4 indicates that the age group consisted of $39.9 \%$ of learners aged between 18 and $25,24.3 \%$ of learners were aged between 26 and 30, and $24.3 \%$ of learners were aged between 31 and 40 . Table 4 also shows that $9.3 \%$ of learners were aged between 41 and 50 and $1.6 \%$ of learners were over 50 years of age.

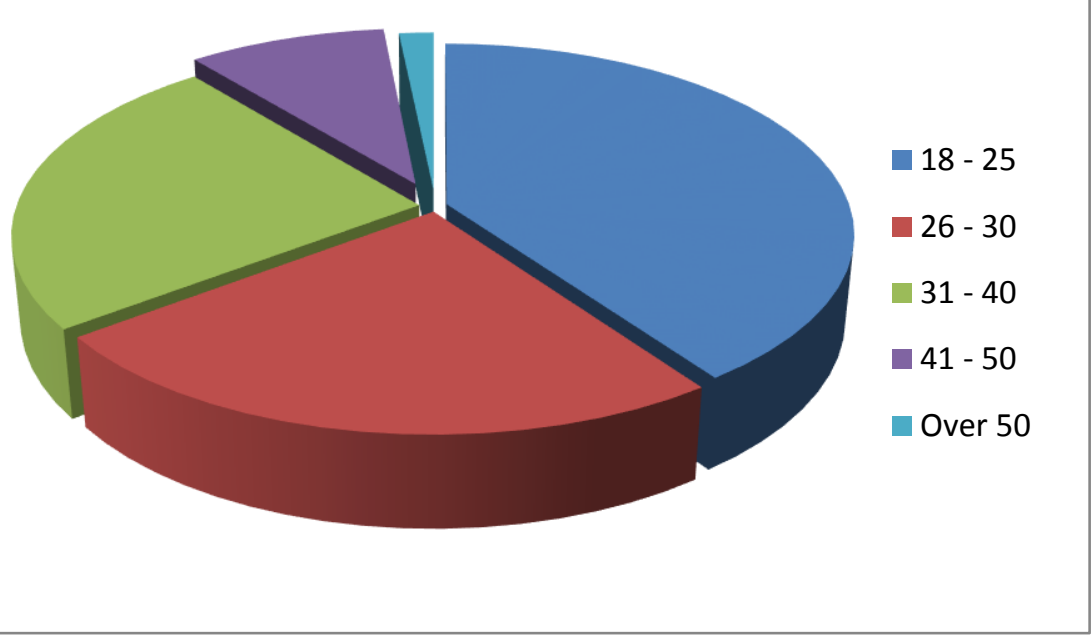

Figure 4. Composition of the age groups.

\section{Measuring Instrument}

In view of the cross-sectional, survey design approach which was adopted in the study, self-report measures were used to collect the data. The selection of the measuring instruments for the purposes of the study was informed by the literature study. The following measuring instruments were used:

- A biographical questionnaire to gather data with regard to gender, race and age

- The newly developed Adult Learner Self-Directedness Scale (ALSDS)

The questionnaire items were obtained through meticulously studying research articles and subject matter books on the topic of self-directedness, as well as the researcher's personal experience with adult learner behaviour in an open distance, comprehensive university. The research on selfdirectedness, with specific reference to the ODLHE environment, was analysed and assimilated in order to determine the relevance of various concepts to the ODLHE milieu. Particular areas of interest that were studied included the concepts of learner motivation, self-efficacy, self-regulation, learner self-directedness in the workplace, learner empowerment, determination to be self-directed, willingness as regards self-direction, student engagement, and coping with study-related problems.

The assimilated principles of adult learning were integrated with what is known about the ODLHE environment in order to determine the types of behaviour adult learners should display in order to ensure successful learning in the higher education, ODL context.

The focus of the ALSDS measuring instrument was to enable adult learners to report on their study behaviours and attitudes and not on their opinions. In the case of the ALSDS, descriptions of the required adult learner behaviours and beliefs in the ODLHE scenario were used as the basis for each scale item and the respondents were required to choose the description which most closely matched 
their own behaviours and beliefs. The purpose of the ALSDS (Botha, 2013) was to assess the four constructs of adult learner self-directedness in an ODLHE milieu, namely:

- the strategic utilisation of officially provided resources;

- engaged academic activity;

- $\quad$ success orientation for ODLHE; and

- academically motivated behaviour.

The biographical questionnaire merely required of students to indicate their gender, age, and race in order to establish the biographical characteristics of the respondents.

\section{Validity and Reliability of the ALSDS}

The results of the Exploratory Factor Analyses revealed that the ALSDS items satisfied the psychometric criteria of both content and construct validity. The internal consistency reliability of the ALSDS was determined using the Cronbach's alpha coefficient. Acceptable internal consistency reliabilities were obtained for the ALSDS. The reliabilities for the four scales varied between .60 and .77 and the total ALSDS scale obtained a Cronbach alpha coefficient of .91 which was considered adequate for the purpose of the study.

The suitability of the data for factor analysis was confirmed by the Kaiser-Meyer-Olkin value of .83 and the Bartlett's Test of Sphericity reached statistical significance, $p<.001$, supporting the factorability of the correlation matrix. These results indicate that the sample used in the study was adequate and that significant correlations exist between the variables of the correlation matrix.

\section{Scoring of the Measuring Instruments}

The responses to each of the instrument measures were imported and analysed using statistical methods, specifically the statistical programmes SPSS (Statistical Package for Social Sciences) Version 20.0 for the Microsoft Windows platform (SPSS Inc., 2011), SAS version 9.2 (SAS, 2008).

\section{Ethical Clearance}

Ethical clearance and permission to conduct the study were obtained from the management and research ethics committee of the ODLHE institution that participated in the study. The questionnaires were mailed to the participants. Each questionnaire included a covering letter to obtain the informed consent of the participants. The covering letter explained the purpose of the research, procedure, potential benefits, confidentiality, anonymity, voluntary participation, and withdrawal. The participants were requested to complete the questionnaires and return them by mail to the researchers.

\section{Statistical Processing of the Data}

A quantitative, cross-sectional, survey research design, focusing on descriptive, correlational and inferential statistical analysis, was used in the empirical study. This study investigated the relationship between self-directedness (as measured by the Adult Learner Self-Directedness Scale) 
and biographical factors such as gender, race, and age of adult learners enrolled at a South African ODLHE institution.

\section{Descriptive Statistics}

The descriptive statistics included frequencies, means, standard deviations, skewness, and kurtosis. The scores across these factors were created by obtaining an average across all the items in each of the factors.

\section{Inferential Statistics}

Inferential statistical analyses (tests for significant mean differences) were performed to determine whether the gender, race, and age groups differed significantly in terms of self-directedness. Based on the test for normality showing that the data were not normally distributed, nonparametric tests were used to test for significant mean differences between the gender (Mann-Whitney U-test), race, and age (Kruskall-Wallis test) groups regarding their self-directedness. The Mann-Whitney U test was used for the comparison of two independent groups (e.g., gender), while the Kruskal-Wallis test was used for the comparison of two or more independent groups (e.g., race and age). The Mann-Whitney analysis may be used instead of a two-sample t-test while the Kruskal-Wallis test may replace the one-way analysis of variance (Nisber, Elder, \& Miner, 2009). The Mann-Whitney U test focuses specifically on determining whether observed data in one population is ranked higher than observed data in another population (Nisber et al., 2009). Although the Mann-Whitney U and Kruskal-Wallis tests are indicated where sample sizes are small $(<100)$, these tests were used in this study because it was not possible to verify the assumption of normality.

\section{Research Results}

The aim of this research was to investigate whether gender, race, and age groups differ significantly regarding self-directedness.

\section{Response Rate}

A response rate of $10.5 \%$ resulted in $\mathrm{N}=1,102$ returned, useable questionnaires. Although a response rate of $20 \%$ would have been preferred, it is not so much the number of the responses but the representivity of the responses that determines the reliability and validity of the results. One of the reasons for the low response rate was the fact that the questionnaires had to be distributed by means of an unreliable postal service. Furthermore, this study formed part of a larger study and the questionnaire consisted of various sections which took considerable time to complete.

\section{Gender}

Table 1 below indicates how the various gender groups differ with regard to the ALSDS constructs.

Table 1

Results of the Mann-Whitney U-test: Gender 


\begin{tabular}{|l|l|l|l|l|l|l|}
\hline & $\begin{array}{l}\text { Mann- } \\
\text { Whitney U }\end{array}$ & Z & $\begin{array}{l}\text { Asymp. } \\
\text { Sig. (2- } \\
\text { tailed) }\end{array}$ & ETA & \multicolumn{2}{|l|}{ Gender Means } \\
\hline $\begin{array}{l}\text { Strategic } \\
\text { utilisation of } \\
\text { officially }\end{array}$ & 135610.000 & -1.085 & .278 & $.001^{* * *}$ & 19.726 & 19.503 \\
\hline $\begin{array}{l}\text { provided resources } \\
\text { Success orientation } \\
\text { for ODLHE }\end{array}$ & 119947.000 & -4.164 & .000 & $.017^{*}$ & 38.357 & 36.614 \\
\hline $\begin{array}{l}\text { Engaged academic } \\
\text { activity }\end{array}$ & 127400.500 & -2.702 & .007 & $.008^{* *}$ & 16.311 & 15.588 \\
\hline $\begin{array}{l}\text { Academically } \\
\text { motivated } \\
\text { behaviour }\end{array}$ & 134805.000 & -1.240 & .215 & $.003^{* *}$ & 49.949 & 50.716 \\
\hline
\end{tabular}

Note. ETA squared values of $\leq .08$ are small in practical effect. ETA squared values of $\geq .09 \leq .24$ are moderate in practical effect. ETA squared values of $\geq .25$ are large in practical effect.

${ }^{*} \mathrm{p} \leq 0.05$.

${ }^{* *} \mathrm{p} \leq 0.01$.

$* * * \mathrm{p} \leq 0.001$

Table 1 shows that males $(M=38.36)$ scored significantly higher than the females $(M=36.61)$ on success orientation for ODLHE $(\mathrm{p}=0.00$; ETA squared $=.017$; small practical effect). Males $(\mathrm{M}=$ 16.31) also scored significantly higher than females $(M=15.59)$ on engaged academic activity $(p=$ 0.01; ETA squared = .01; small practical effect).

The findings of this study are supported by other studies with regard to success orientation but not with regard to engaged academic activity.

From an African perspective, males continue to play a dominant role in the community and are expected to be successful and fulfil managerial roles. It was not until recently that women started to enter the workforce and aspire to managerial positions. In the majority of cases, females continue to assume submissive roles in the labour market hence less emphasis on achieving success. This explanation is supported by Veira and Grantham (2011), who found that males scored significantly higher than females on success orientation. The findings of the self-directedness study also support the findings of Mackay and Parkinson (2008) as regards the self-efficacy of female students in study areas that are traditionally considered to be the domain of males in South Africa. 
According to Chang et al. (2013), female learners possess meaningfully lower perceived levels of internet self-efficacy than male learners. This would explain why female learners would be less prepared than male learners to engage in online academic activities and make use of online learning resources. Veira and Grantham (2011) found that female learners set more difficult goals than men, although male learners would be more willing than female learners to take on challenging tasks because of their well-developed, self-efficacy beliefs.

Interestingly, the findings of this study do not support the findings of Tison, Bateman, Steven, and Culver (2011) who found the academic engagement of females being significantly higher than that of the males. In a study conducted by Enache, Sallan, Simo, and Fernadez (2011) women's career success was found to be positively related to their self-directedness. Thus, in this regard, it would appear that the findings of this study do not support current reported research.

\section{Race}

Table 2 below indicates how the various race groups differ with regard to the ALSDS constructs.

Table 2

Results of the Kruskall-Wallace Test: Race

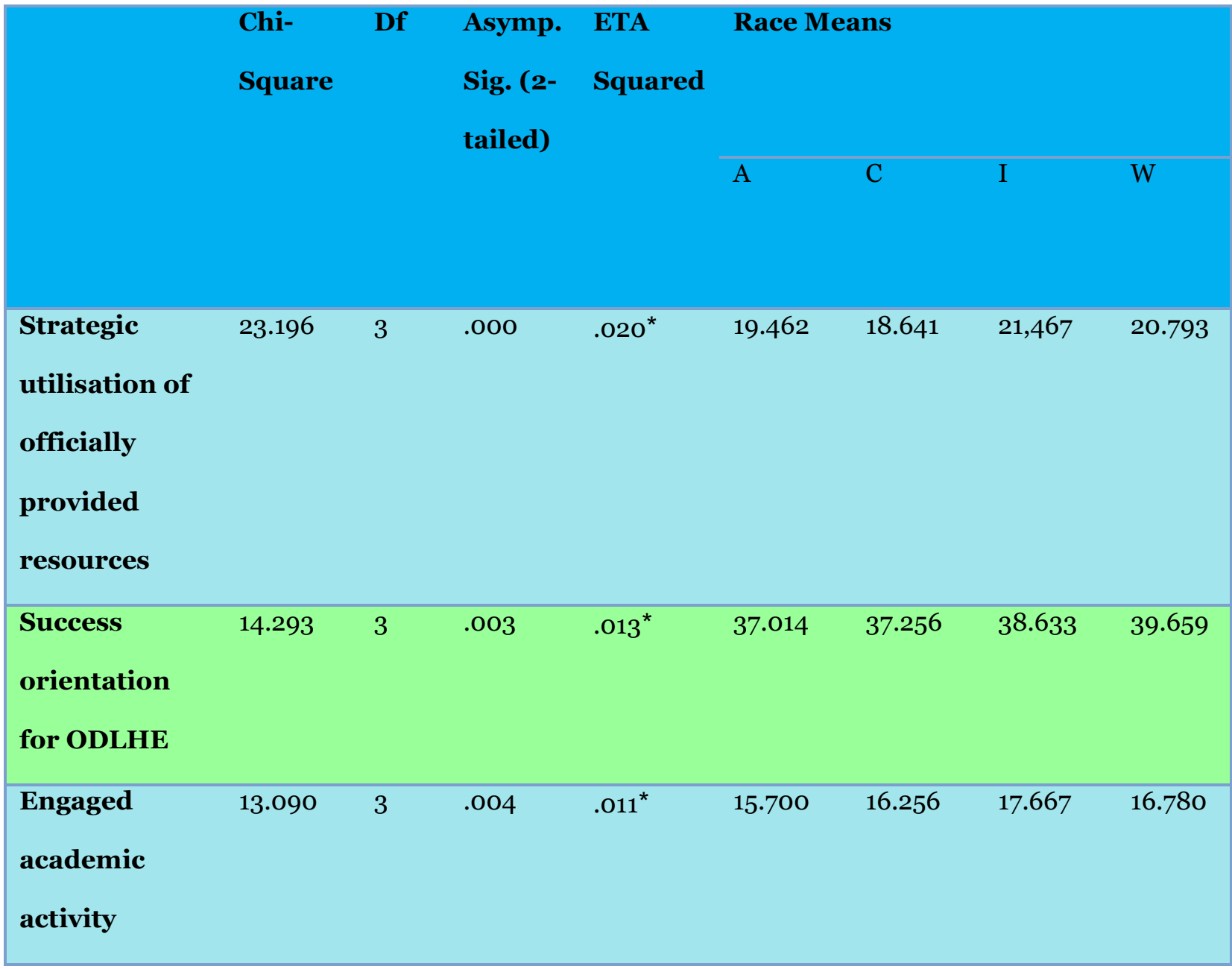




\begin{tabular}{lllllllll|}
\hline $\begin{array}{l}\text { Academically } \\
\text { motivated }\end{array}$ & 4.039 & 3 & .257 & $.003^{* \star}$ & 50.560 & 48.718 & 49.933 & 49.805 \\
behaviour & & & & & & & & \\
\end{tabular}

Note. ETA squared values of $\leq .08$ are small in practical effect. ETA squared values of $\geq .09 \leq .24$ are moderate in practical effect. ETA squared values of $\geq .25$ are large in practical effect. $\mathrm{A}=$ Africans; $\mathrm{C}=$ Coloureds; I = Indians; $\mathrm{W}$ = Whites.

${ }^{*} \mathrm{p} \leq 0.05$.

${ }^{* *} \mathrm{p} \leq 0.01$.

*** $\mathrm{p} \leq 0.001$.

Table 2 shows that the Indian participants scored significantly higher than the other race groups on strategic utilisation of officially provided resources $(\mathrm{M}=21.47 ; \mathrm{p}=.00$; ETA squared $=.02$; small practical effect $)$ and engaged academic activity $(\mathrm{M}=17.67 ; \mathrm{p}=.004$; ETA squared $=.011$; small practical effect). The white participants scored significantly higher than the other race groups on success orientation for ODLHE $(\mathrm{M}=39.66 ; \mathrm{p}=.003$; ETA squared $=.013$; small practical effect $)$.

The Coloured participants scored significantly lower than the other race groups on strategic utilisation of officially provided resources ( $\mathrm{M}=18.641 ; \mathrm{p}=.000$, ETA squared $=.013$; small practical effect). The African participants obtained significantly lower scores than the other race groups on success orientation for ODLHE ( $\mathrm{M}=37.01, \mathrm{p}=.003$; ETA squared $=.013$; small practical effect $)$ and engaged academic activity $(\mathrm{M}=15.70 ; \mathrm{p}=.004$; ETA squared $=.011$; small practical effect $)$.

The low success orientation and academic activity of Blacks could be the result of previous discrimination practices which did not provide Blacks with opportunities to advance to top positions or be exposed to technology and learning opportunities that would have assisted them in successfully engaging in tertiary education. Similarly, Coloureds have also not been in a favourable position to advance academically and hence the low utilization of resources by this group. In contrast to the disadvantaged positions that Blacks and Coloureds experienced in the past, Indians are much more familiar with academic achievement and technology and are often in a better financial situation to utilize resources and engage in the academic activities provided by the university. Another significant reason for some student groups' lack of productive engagement with the learning materials may be related to the languages of instruction at the university (Coetzee-Van Rooy, 2010). The two main languages of instruction are English and Afrikaans. In a study on the success of students of Microeconomics conducted at the same institution, Pretorius, Prinsloo, and Uys (2009) found a significant relationship between student success and language of instruction, with those students whose home language was also one of the languages of instructing, faring significantly better in Micro-Economics. Furthermore, the social contexts in which school children are educated may vary significantly, consequently influencing the way students eventually interact with and utilise the learning materials provided in tertiary education (Smith, 2015). The preferential treatment of Whites in terms of jobs and occupying managerial positions have resulted in a situation where the drive to succeed is strongly embedded in their culture, hence this group scoring significantly higher than the other groups on success orientation. 


\section{Age}

Table 3 below indicates how the various age groups differ with regard to the ALSDS constructs.

Table 3

Results of the Kruskall-Wallace Test: Age

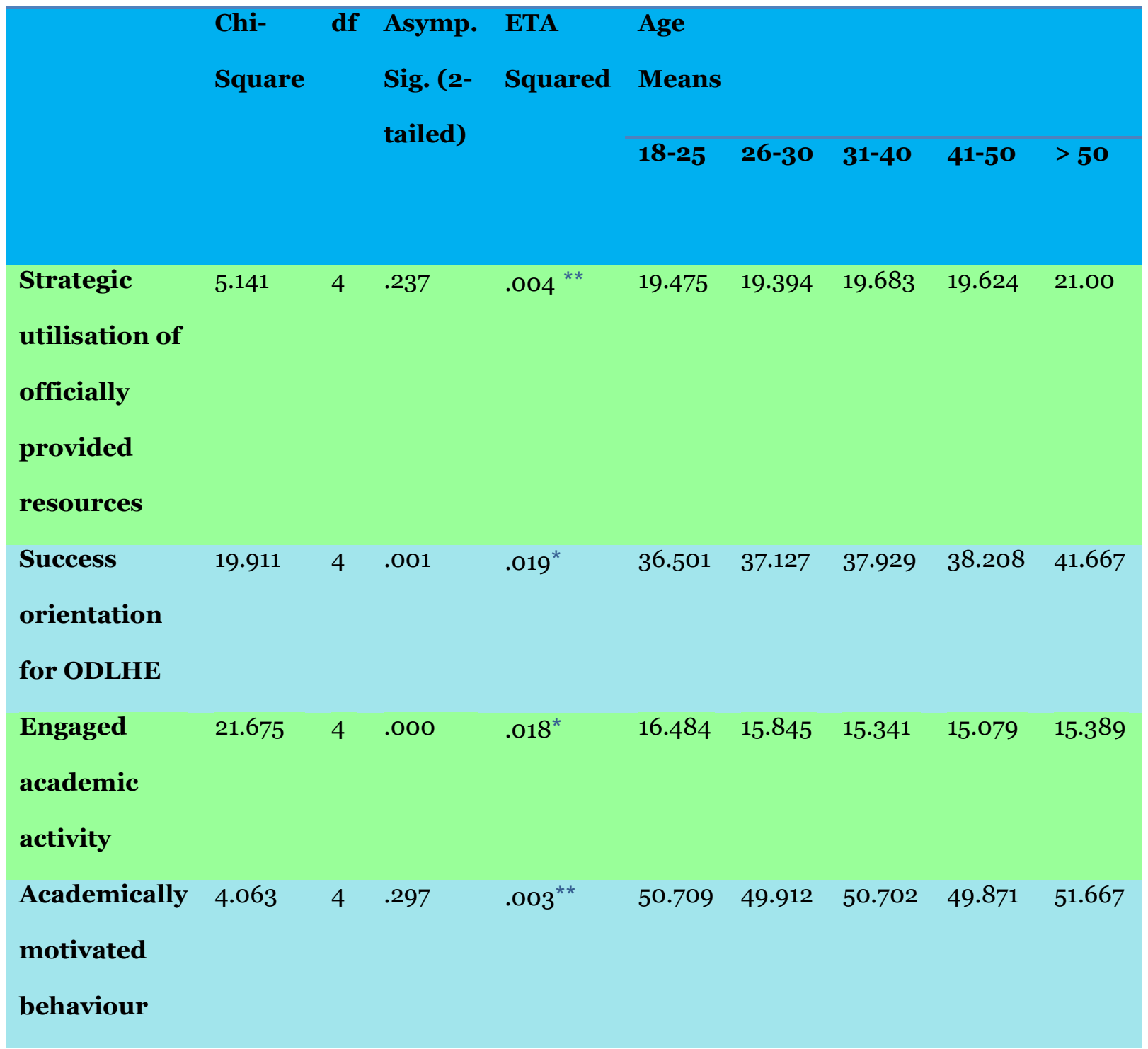

Table 3 shows the age group $>50$ scored significantly higher than the other age groups on success orientation for ODLHE $(\mathrm{M}=41.67 ; \mathrm{p}=.001$; ETA squared $=.019$; small practical effect $)$ and selfefficacy $(\mathrm{M}=28.94 ; \mathrm{p}=.03$; ETA squared $=.01$; small practical effect $)$. In terms of success orientation, the means for the age groups seem to increase as the ages of participants increase. Older learners have acquired experience, confidence and self-belief and would be much more driven by success than younger learners who have not yet mastered the necessary life skills.

The age group 41-50 scored significantly lower than the other age groups on self-efficacy ( $M=27.53 ; p$ $=.03 ;$ ETA squared $=.01 ;$ small practical effect $)$. 
The age group 18-25 scored significantly lower than the other age groups on success orientation ( $\mathrm{M}=$ 36.501). This finding supports the findings of Reio and Davis (2005) that age relates significantly to readiness for self-directed learning, and that readiness for self-directed learning increases significantly as age increases.

In terms of the variable engaged academic activity, the age group 18-25 scored significantly higher than the other age groups $(\mathrm{M}=16.484, \mathrm{p}=.000$; ETA squared $=.018$; small practical effect). This may possibly be explained by the multi-faceted life roles and responsibilities of the learners in the age group 41 to 50 as opposed to the learners in the age group 18 to 25. Younger learners would probably have the technological know-how and time to engage in academic activities. It may also be explained by previous learning experiences which may have influenced the participants' learning behaviours. The age group 18 to 25 who find themselves in their early career stages may be more interested in, and motivated for, further study in order to advance their careers than the other age groups (Ferreira \& Coetzee, 2010). Another reason for this finding may be the perception of older adults that they are not suitable candidates for tertiary education in terms of the economic impact studying may have on them, as well as, in terms of the social risk they may feel they are taking when enrolling in tertiary education (Boeren, 2011; Howard \& Davies, 2012). The age group 18-25 scored significantly lower than the other age groups on success orientation $(\mathrm{M}=26.50, \mathrm{p}=.001$; ETA squared $=.019$; small practical effect). This could be due to the fact that younger learners focus on achieving short term goals such as completing a qualification rather than on achieving success in the future.

An overview is provided in table 4 of the core differences observed between the gender, race, and age groups in terms of the ALSDS variables.

Table 4

Summary of the Significant Differences between Gender, Race and Age in terms of the ALSDS

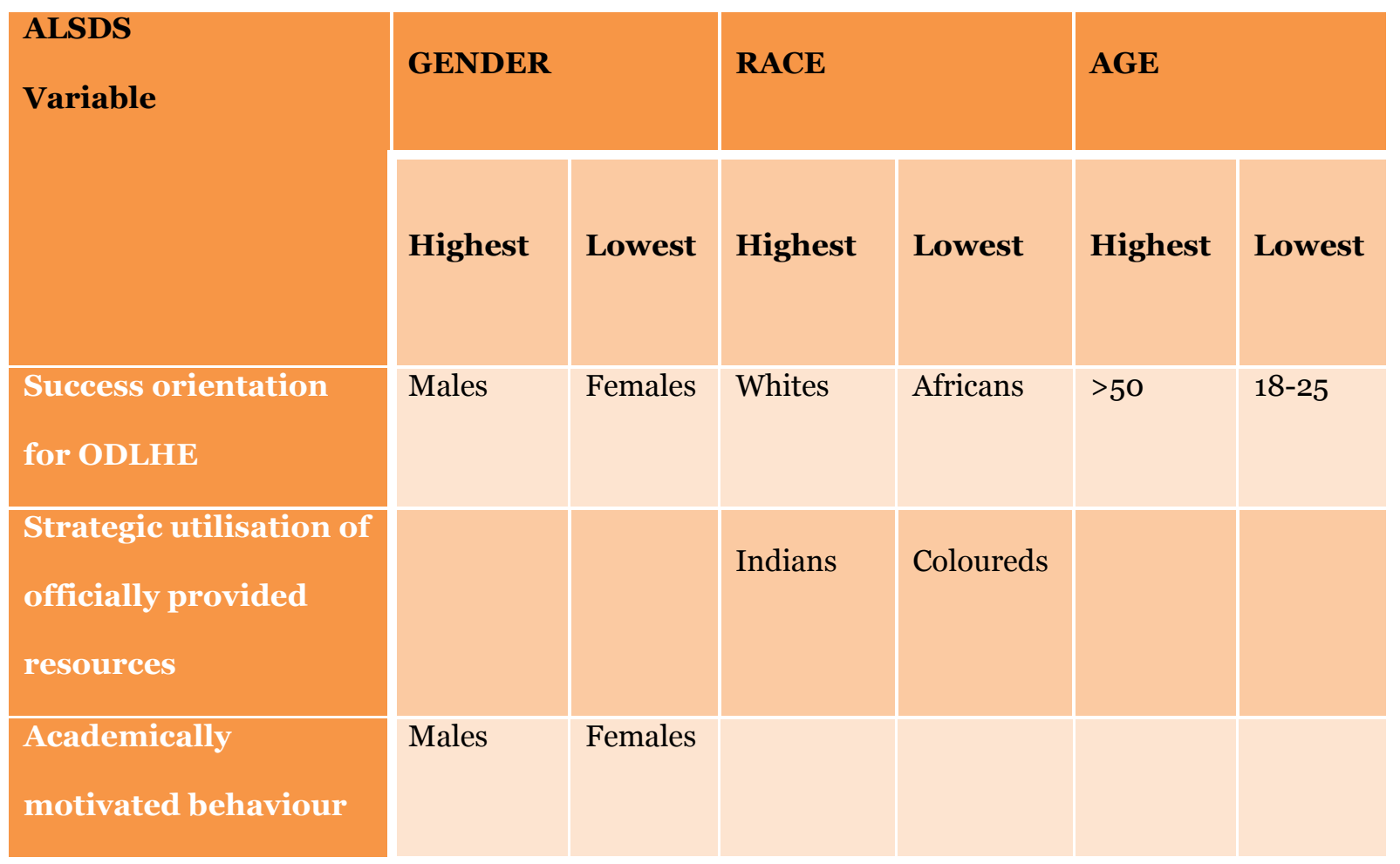




\begin{tabular}{l|l|l|l|l|l|l|l|l|}
\hline Engaged academic & Indians & Africans & $18-25$ & $41-50$ \\
activity &
\end{tabular}

\section{Conclusion}

South Africa is aiming to address the current skills shortages by means of the occupational learning system and by focusing on occupationally relevant learning. This approach aims to develop not only the skills of employees, but also their employability. Employers may be content with the subject-or domain-specific skills that their employees acquire during tertiary education but there are indications of increased dissatisfaction with the employability skills of employees. Employers in the new millennium require employees who are able to be innovative, manage their own career progression autonomously, identify and solve work-related problems creatively, and work well in groups composed of various cultural, race, age, and gender groups. Career management and employability both require self-directedness, as does ODLHE studies. The demands of the South African labour market have created a situation in which an increasing number of adult learners are participating in ODLHE. This increased participation of adults in formal learning opportunities has resulted in the need to explore the way in which adults learn best and to identify the approaches to be adopted by ODLHE institutions. This study confirms that gender, race, and age groups differ significantly regarding self-directedness. Accordingly, ODLHE institutions should design and offer qualifications in such a manner that it takes into consideration the unique abilities and preferences of the various gender, race, and age groups. 


\section{References}

Boeren, E. (2011). Profiles and motives of adults in Flemish continuing education. European Journal of Higher Education, 1(2-3), 179-191.

Botha, J. (2014). The relationship between adult learner self-directedness and employability attributes - an ODL perspective. (Unpublished master's thesis). University of South Africa, Pretoria.

Canning, N. (2010). Playing with heutagogy: Exploring strategies to empower mature learners in higher education. Journal of Further and Higher Education, 34(1), 59-71.

Cassidy, S. (2006). Developing employability skills: Peer assessment in higher education. Education \& Training, 48(7), 508-517.

Cassidy, S. (2011). Self-regulated learning in higher education: Identifying key component processes. Studies in Higher Education, 36(8), 989-1000.

Chan, C-S., Liu, E. Z-F., Sung, H-Y., Lin, C-H., Chen, N-S., \& Cheng, S-S. (2013). Effects of online college students' self-efficacy on learning motivation and performance. Innovations in Education and Teaching International, 51, 366-377, DOI: 10.1080/147039297.2013.771429.

Coetzee, M., \& Botha, J. (2013). Undergraduate students' self-directedness in relation to their examination preparation styles in Open Distance Learning. Progressio, 35(2), 34-57.

Coetzee-Van Rooy, S. (2010). Complex systems, multilingualism and academic success in South African higher education. Southern African Linguistics and Applied Language Studies 2010, 28(4), 309-321

Diniz, E, Piccolo, D.L, Couto, D.M.C.P, Salles, J.F., \& Koller, H.S. (2014). Influences of developmental contexts and gender differences on school performance of children and adolescents. Educational Psychology, 34(7), 787-798.

Du Plessis, A., Prinsloo, P., \& Muller, H. (2005). Determining the profile of the successful first-year accounting student. South African Journal of Higher Education, 19(4), 684-698.

Dzakira, H., \& Idrus, R.M. (2003). Teacher-learner interactions in distance education: A case of two Malaysian Universities. Turkish Online Journal of Distance Education, 4(3). Retrieved from http://scholar.google.co.za/scholar?q=Turkish+online+journal+of+distance+education.

Edmondson, D.R., Boyer, S.L., \& Artis, A.B. (2012). Self-directed learning: A meta-analytic review of adult learning constructs. International Journal of Education Research, 7(1), 40-48.

Enache, M., Sallan, J.M., Simo, P., \& Feernadez, V. (2011). Career attitudes and subjective career success: Tackling gender differences. Gender in Management: An International Journal, 36(3), 234-250.

Faber, K., Lopez, V., \& Prescher, T. (2012). i-learn: Developing a new approach in higher education for lifelong learning. European Journal of Higher Education, 2(2-3), 218-233. 
Ferreira, N., \& Coetzee, M. (2010). Psychological career resources and organisational commitment: Exploring sociodemographic differences. South African Journal of Labour Relations, 34(2), 25-35.

Garrison, D.R. (1997). Self-directed learning: Toward a comprehensive model. Adult Education Quarterly, 48(1), 18-33.

Goomas, D.T., \& Clayton, A. (2013). New-to-college "academic transformation" distance learning: A paradox. Community College Journal of Research and Practice, 37(11), 915-918.

Griesel, H., \& Parker, B. (2009). Graduate attributes. Pretoria: Higher Education South Africa.

Hampden-Tompson, G., \& Bennett, J. (2013). Science teaching and learning activities and students' engagement in science. International Journal of Science Education, 35(8), 1325-1343. DOI: 10.1080/09500693.2011.608093

Heydenrych, J.F., \& Prinsloo, P. (2010). Revisiting the five generations of distance education: Quo Vadis? Progressio, 31(10), 5-26.

Howard, C., \& Davies, P. (2012). Attracting mature students into higher education: The impact of approaches to learning and social identity. Journal of Further and Higher Education, 37(6), 769-785. DOI: 10.1080/0309877X.2012.684038.

Huang, C. (2013). Gender differences in academic self-efficacy: A meta-analysis. European Journal of Psychology Education, 28, 1-35.

Ivala, E.N. (2011). Globalisation: The role of new information and communication technologies in distance education. Africa Education Review, 8(1), 79-101.

Karakas, F., \& Manisaligil, A. (2012). Reorienting self-directed learning for the creative digital era. European Journal of Training and Development, 37(7), 712-731.

Kasworm, C. (2011). New perspectives on post-formal cognitive development and self-directed learning. International Journal of Self-Directed Learning, 8(1), 18-28.

Knowles, M.S. (1984). Andragogy in action. California: Jossey-Bass.

Liddell, T.N. (2008). Executive women's self-directed learning and leading in charitable foundations. International Journal of Self-directed Learning, 5(1), 15-29.

Mackay, J., \& Parkinson, J. (2008). Gender, self-efficacy and achievement among South African Technology teacher trainees. Gender and Education 22(1), 87-103.

Magagula, C.M., \& Ngwenya, A.P. (2004). A comparative analysis of the academic performance of distance and online campus learners. Turkish Online Journal of Distance Education, 5(4). Retrieved from http://scholar.google.co.za/scholar?q=Turkish+online+journal+of+distance+education 
Markes, I. (2006). A review of literature on employability skills needs in engineering. European Journal of Engineering Education, 31(6), 637-650.

Mezirow, J. (2000). Learning as transformation: Critical perspectives on a theory in progress. San Francisco, CA: Jossey-Bass.

Moore, M. (1990). Recent contributions to the theory of distance education. Open Learning: The Journal of Open, Distance and e-Learning, 5(3), 10-15.

Nisber, R., Elder, J., \& Miner, G. (2009). Handbook of statistical analysis and data mining applications. Massachusetts: Elsevier.

Oliviera, A.L., \& Simões, A. (2006). Impact of socio-demographic and psychological variables on the self-directedness of higher education students. International Journal of Self-Directed Learning, 3(1), 1-12.

O’Toole, S., \& Essex, B. (2012). The adult learner may really be a neglected species. Australian Journal of Adult Learning, 52(1), 183-191.

Potgieter, I., Coetzee, M., \& Masenge, A. (2012). Exploring employees' personality attributes in relation to their employability attributes in the Business Management field. Journal of Psychology in Africa, 22(4), 589-597.

Pretorius, A.M., Prinsloo, P., \& Uys, M.D. (2009). Student performance in Introductory Microeconomics at an African open and distance learning institution. Africa Education Review, 6(1), 140-158.

Prinsloo, P. (2009). Modelling throughput at Unisa: The key to the successful implementation of ODL. (Working Paper 2012-07-13To7:34:52Z). Retrieved from http://hdl.handle.net/10500/6035

Prinsloo, P., Müller, H., \& Du Plessis, A. (2010). Raising awareness of the risk of failure in first-year accounting students. Accounting Education: An International Journal, 19(1-2): 203-218.

Rehfuss, M.C. (2005). The effect of self-directedness on the academic success of medical students. Dissertation Abstracts International Section A: Humanities and Social Sciences, 65(11-A): 4118. Retrieved from http://web.b.ebscohost.com/ehost/detail/detail/.

Reio, T.G., \& Davis, W. (2005). Age and gender differences in self-directed learning readiness: A developmental perspective. International Journal of Self-Directed Learning, 2(1), 40-49.

Richardson, T.E. (2011). The academic engagement of white and ethnic minority students in distance education. Educational Psychology, 31(2), 123-139.

SAS Institute Inc. (2008). SAS/STAT®9.2 User's guide. Cary, NC: SAS Institute Inc.

Shillington, S., Brown, M., MacKay, A., Paewai, S, Suddaby, G., \& White, F. (2012). Avoiding the goulash: Closing gaps and bridging distances. Open Learning: The Journal of Open, Distance and e-Learning, 27(1), 65-80. DOI:10.1080/02680513.2012.640789 
Seta, L., Kukulska-Hulme, A., \& Arrigo, M. (2014). What have we learnt about mobile Lifelong Learning (mLLL)? International Journal of Lifelong Education, 33(2), 161-182. DOI: 10.1080/02601370.2013.831954.

Smith, E. (2015). Can higher education compensate for society? Modelling the determinants of academic success at university. British Journal of Sociology of Education, 1465-3346. DOI: 10.1080/01425692.2014.987728

SPSS Inc. (2011). IBM SPSS Statistics for Windows, Version 20.0. Armonk, NY: IBM Corp.

Stevens, T., \& Switzer, C. (2006). Running ahead: Online and traditional student differences. Turkish Online Journal of Distance Education, 7(2). Retrieved from http://scholar.google.co.za/scholar?q=Turkish+online+journal+of+distance+education.

Subotzky, G., \& Prinsloo, P. (2011). Turning the tide - a socio-critical model and framework for improving student success in ODL at the University of South Africa. Distance Education, 32(2), 177-193.

Sumner, J. (2000). Serving the System: A critical history of distance education. Open Learning: The Journal of Open, Distance and e-Learning, 15(3), 267-285.

Taipjutorus, W., Hansem, S., \& Brown, M. (2012). Investigating the relationship between learner control and self-efficacy in an online learning environment. Journal of Open, Flexible and Distance Learning, 16(1), 56-69.

Tison, E.B., Bateman, T., \& Culver, M. (2011). Examination of the gender-student engagement relationship at one university. Assessment \& Evaluation in Higher Education, 36(1), 27-49.

Tucker, S.T. (2003). A portrait of distance learners in higher education. Turkish Online Journal of Distance Education, 4(3). Retrieved from http://scholar.google.co.za/scholar?q=Turkish+online+journal+of+distance+education.

Väljataga, T., \& Laanpere, M. (2010). Learner control and personal learning environment: A challenge for instructional design. Interactive Learning Environments, 18(3), 277-291. DOI: 10.1080/10494820.2010.500546.

Veira, E.T., \& Grantham, S. (2011). University students setting goals in the context of autonomy, selfefficacy and important goal-directed task engagement. Educational Psychology: An International Journal of Experimental Educational Psychology, 31(2): 141-156.

Walker. L., Matthew, B., \& Black, F. (2004). Widening access and student non-completion: an inevitable link? Evaluating the effects of the Top-Up Programme on student completion. International Journal of Lifelong Education, 23(1), 43-39.

Wardley, J.E., Bélanger, C.E., \& Leonard, V.M. (2013). Institutional commitment of traditional and non-traditional-aged students: a potential brand measurement? Journal of Marketing for Higher Education, 23(1), 90-112. 
Yahya, K., \& Javad, S. (2014). A sociolinguistic study of gender differences in Persian written performance. Modern Journal of Language Teaching Methods, 4(1), 209-227.

\section{Athabasca}

University

(c) (†) 